\title{
Pine (Pinus Eldarica Medw.) needles as indicator for heavy metals pollution
}

\author{
${ }^{1 *}$ B. Kord; ${ }^{2}$ A. Mataji; ${ }^{2}$ S. Babaie \\ ${ }^{1}$ Department of Green Space Engineering, Malayer Branch, Islamic Azad University, Malayer, Iran \\ ${ }^{2}$ Department of Forestry, Science and Research Branch, Islamic Azad University, Tehran, Iran \\ Received 29 May 2009; $\quad$ revised 17 August 2009; accepted 1 November 2009; available online 1 December 2009
}

\begin{abstract}
In this study, the pine tree (Pinus Eldarica Medw.) needles were evaluated as the biomonitors of heavy metal contamination in Tehran, Iran. The pine needle samples supplied from the old trees according to the main wind direction (highest wind speed) were obtained from each parts of tree and then were homogeneously mixed. The samples were taken from different locations with different degrees of metal pollution (urban, industrial, highway and control sites). Then, the concentrations of lead, zinc, copper, nickel and chromium were measured using a flame atomic absorption spectrophotometer. The result of this study showed that the highest and the lowest metal concentrations were found in the heavy traffic sites and the control site, respectively. However, samples taken from highway sites contained the high concentrations of nickel, copper and lead. Moreover, industrial areas were found to have high contents of zinc and chromium. The variation in heavy metal concentrations between the studied locations is due to changes in traffic density and anthropogenic activities. This research proved significant correlations between the heavy metal concentrations in pine needle samples. Finally, it is concluded that Pinus Eldarica Medw. needles can be applied to monitor polluted sites.
\end{abstract}

Keywords: Air pollution; Atomic absorption spectrophotometer; Biomonitor; Heavy metals; Pine tree

\section{INTRODUCTION}

Increasing of anthropogenic activities leads to the emission of various pollutants into the environment and different types of hazardous substances are consequently appeared into the atmosphere (Onder and Dursun, 2006; Kho et al., 2007). Air pollution due to increased human activity is aesthetically offensive and can be a genuine health hazard to human, as well as vegetation, plants and micro-organisms (Boddy et al., 1994; Dursun et al., 2002; Gbaruko and Friday, 2007). The use of plant tissues in sampling has long been shown to be an effective indicator of atmospheric pollution (Goodman and Roberts, 1971). Vegetation is a proper indicator to assess the impact of a pollution source on the vicinity which is due to high metal accumulation of plants (Onder and Dursun, 2006). Furthermore, the observed effect is a time-averaged result, which will be more reliable than direct

*Corresponding Author Email: behrouzkord@yahoo.com Tel.: +98851 222 7878; Fax: +98851 2228236 determination of the pollutant concentrations in air, for a short period. The emission of toxic substances in the environment has been spread from industrialized countries. Many industrial plants and also heavy traffic may produce heavy metal into the atmosphere. Traffic pollutants include potentially toxic metals for health such as lead, zinc and cadmium (Viard et al., 2004; Duran and Gonzalez, 2009). Heavy metals are among the pollutants that need to be removed from contaminated sites. They are considered hazardous contaminants that can accumulate in the human body, with a relatively long half-life. For instance, it has been stated that, Cd has a half-life of 10 years in the human body (Salt et al., 1995). Heavy metals cause serious environmental risks and therefore, its effect has been examined extensively (Abdel-Ghani et al., 2007). Uptake of elements into plants can happen via different ways. The elements can be taken up via roots from soil and transported to the leaves; also they may be taken 
up from the air, or by precipitation directly via the leaves. Trace elements may be also taken up via the mentioned ways. Biological monitors and vegetations are used to measure the levels of atmospheric trace metal concentration (Onianwa et al., 1986; Onasanya et al., 1993; Wolterbeek et al., 1996; Celik et al., 2005; Nabulo et al., 2008). Biological monitors are applied as the cheapest and simplest indicator for monitoring the trace metal concentrations in the atmosphere. Numerous different bio-indicators are used in monitoring air pollution, such as mosses, lichens, vascular plants, woody plants, etc. Both the broadleaves and coniferous trees are used in air pollution studies (Löstschert and Köhm, 1978; Grodzinka, 1982; Huhn et al., 1995; Lippo et al., 1995; Adeniyi, 1996). The aim of this work is to determine the pollution levels (concentrations) of $\mathrm{Pb}, \mathrm{Cu}, \mathrm{Zn}, \mathrm{Ni}$ and $\mathrm{Cr}$ in the atmosphere of Tehran city using pine tree (Pinus Eldarica Medw.) needles as a bio-indicator. The result could be used as preliminary baseline data for trace elements concentrations in the ecosystems for future assessment and monitoring.

\section{MATERIALS AND METHODS}

Study area

Tehran is the capital city of Iran, which has an elevation of around $1400 \mathrm{~m}$ above sea level, at latitude $\left(35^{\circ} 50^{\prime} \mathrm{N}\right)$ and longitude $\left(51^{\circ} 37^{\prime} \mathrm{E}\right)$. The average annual precipitation in the investigated area is 246 $\mathrm{mm} / \mathrm{y}$. Minimum temperature is $4.5^{\circ} \mathrm{C}$ in January and maximum temperature $31.5^{\circ} \mathrm{C}$ in August. Relative humidity during daytime is relatively low ranging from $28 \%$ in June to $64 \%$ in December. The city suffered from high traffic density caused by vehicles. The average number of vehicle movements per hour in urban, industrial, highway and control sites of the study area are $360,315,1400$ and $<50$, respectively. Nowadays, Pine (Pinus eldarica Medw.) covers the majority of urban trees in Tehran due to it's ever greenness (Fig. 1).

\section{Sampling and analysis}

The pine needles were collected from old trees about 20-25 years old during July and August 2007. Pine trees are widespread in Tehran with evergreen needle normally 3-5 inches irregularly twisted (Fig. 2).

All of trees were identified according to the documents obtained from the Tehran Municipality and Green Space Organization (Tehran Municipality, 2007).

The needle samples supplied from the trees according to the main wind direction (i.e. the highest wind speed) were obtained from each parts of tree and then were homogeneously mixed. The total number of collected samples was 53, distributed as follows: 15 samples from the urban, industrial and highway sites and 8 samples were from control site. The samples were separately collected into clean cellulose bags and brought to the laboratory on the same day. In laboratory, the samples were carefully washed three times with distilled water to remove adhering particle (Babaoglu, et al., 2004). All needle samples were weighed and then dried in an oven at $70{ }^{\circ} \mathrm{C}$ for $48 \mathrm{~h}$. The samples $(1 \mathrm{~g})$ of finely ground needles were digested with concentrated $\mathrm{HNO}_{3}$ in a microwave system. Heavy metal concentrations were measured by the flame atomic absorption spectrophotometer, Perkin-Elmer AAS analysis 300 model, with three replicates. Used metal standards were provided from Merck, Germany. The analysis of variance (ANOVA) was used to compare the significant difference in the mean concentration of heavy metals between the sampling sites. $F$ is a parameter in the level of $5 \%$. Pearson's correlation coefficient was used to measure the degree of correlation between logarithms of the metal concentrations. ANOVA test and Pearson's

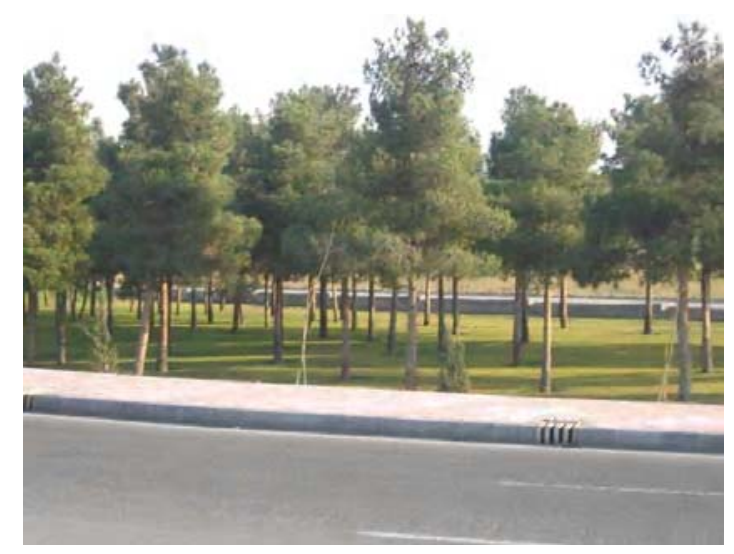

Fig 1: Pine trees community cover arrround the traffic zone of urban area in Tehran 


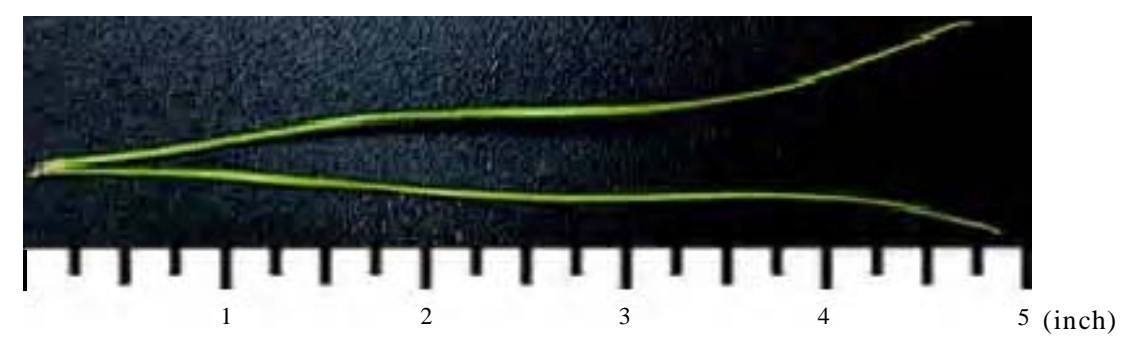

Fig. 2: Evergreen needle; $3-5$ inches with thin and irregularly twisted

correlation coefficient were performed using the SPSS statistical program.

\section{RESULTS AND DISCUSSION}

Heavy metal concentrations in sampled pine needles are shown in Table 1 . The results indicate that the highest and the lowest metal concentrations were found in the heavy traffic sites and the control site, respectively. The mean metal concentration values are arranged in the following order: $\mathrm{Pb}>\mathrm{Zn}>$ $\mathrm{Ni}>\mathrm{Cu}>\mathrm{Cr}$. The Lead, nickel and copper content were found at high concentrations in the highway sites, whereas industrial areas contained high concentrations of zinc and chromium. The correlations of metal content in samples collected of Tehran are shown in Table 2. There are many high significant correlation coefficients between heavy metals in all sampling sites, such as $\mathrm{Pb}$ vs. $\mathrm{Cu}, \mathrm{Ni}$ and $\mathrm{Zn}$ ( $\mathrm{r}=0.83,0.79$ and 0.77 , respectively), $\mathrm{Zn}$ vs. $\mathrm{Ni}$, and $\mathrm{Cu}(\mathrm{r}=0.78$, and 0.76 , respectively), and also $\mathrm{Cu}$ vs. $\mathrm{Ni}(\mathrm{r}=0.75)$. This indicated that the origin of metal in the investigated area is related to heavy traffic, industrial activities, structure of the soil and street dust emission. Any meaningful correlation was not found between $\mathrm{Cr}$ vs. $\mathrm{Pb}, \mathrm{Cu}, \mathrm{Zn}$ and $\mathrm{Ni}$ because of low Cr concentration. The analysis of variance of heavy metal concentrations between the sampling sites are shown in Table 3 . The results indicated that there are significant difference in $\mathrm{Pb}, \mathrm{Cu}$ and $\mathrm{Ni}$ concentrations in pine trees samples collected from different sites. However, no significant differences were found for the rest of elements. This can be attributed to different anthropogenic activities between the sites. The $\mathrm{Pb}$ levels were the lowest at the control site (14.1 ppm) and the highest at highway sites (62.3 ppm), which have higher traffic density.
The chemical form of lead is of critical importance, since this is a factor in movements into plant, translocation and the toxic effectiveness of lead within the plant. Lead pollution on a local scale is caused by emissions from motor vehicle using leaded gasoline (Koeppe, 1981; Yilmaz and Zengin, 2003; Viard et al., 2004). Normal content of $\mathrm{Pb}$ in plants is less than 10 ppm (Kabata-Pendias and Piotrowska, 1984). Allen (1989) considered a much lower value of 3 ppm as a normal natural level for plants. The close relationship between lead concentrations and traffic intensity has been demonstrated in detail by many authors (Gromov and Emelina, 1994; Li et al., 2001; Viard et al., 2004). In this research, there was a linear correlation between high $\mathrm{Pb}$ level and heavy traffic at Tehran city. The degree of metals content in the pine needles was found to be proportional to industrial, human activities and urbanization. High metal concentrations in plants are contianed in industrial sites and urban and highway roadsides due to the anthropogenic activities in addition to the traffic density (Celik et al., 2005). Zinc is an essential element in all organisms and considered an important factor in the biosynthesis of enzymes, auxins and some proteins. Plants with symptoms of $\mathrm{Zn}$ deficiency experience a retarded elongation of cells. A critical toxic level of $\mathrm{Zn}$ in the leaves is about $100 \mathrm{ppm}$ in dry plant matter (Allen et al., 1974; Yilmaz and Zengin, 2003). The high contents of zinc in leaves and plant roots may cause the loss of food production and the low levels in plants may cause deformation of leaves (Bucher and Schenk, 2000; Celik et al., 2005; Kashem et al., 2007). The level of zinc in plant samples decreases with decreased traffic density (Table 1). Copper is minor trace metal, with $70 \%$ copper in leaves contained in the chloroplast of land plants (Wilkinson, 1994). It is an important 
Heavy metals pollution indicator

Table 1: Heavy metal content (ppm) of pine tree needles collected from different sites in Tehran city

\begin{tabular}{|c|c|c|c|c|}
\hline Parameters & Urban & Highway & Industrial & control \\
\hline $\mathrm{Pb}$ & 39.8 & 62.3 & 42.6 & 14.1 \\
\hline $\mathrm{Zn}$ & 14.46 & 18.49 & 24.16 & 1.53 \\
\hline $\mathrm{Cu}$ & 7.93 & 15.43 & 10.6 & 2.5 \\
\hline $\mathrm{Ni}$ & 10.16 & 16.7 & 13.2 & 1.86 \\
\hline $\mathrm{Cr}$ & 2.04 & 3.15 & 3.97 & 0.39 \\
\hline
\end{tabular}

Table 2: Correlation of metal concentration in pine trees $(n=53)$

\begin{tabular}{|c|c|c|c|c|}
\hline Parameters & $\mathrm{Pb}$ & $\mathrm{Zn}$ & $\mathrm{Cu}$ & $\mathrm{Ni}$ \\
\hline $\mathrm{Pb}$ & & & & \\
\hline $\mathrm{Zn}$ & 0.77 & & & \\
\hline $\mathrm{Cu}$ & 0.83 & 0.76 & & \\
\hline $\mathrm{Ni}$ & 0.79 & 0.78 & 0.75 & \\
\hline $\mathrm{Cr}$ & 0.28 & 0.11 & 0.19 & 0.09 \\
\hline
\end{tabular}

Table 3: The result of statistical analysis (ANOVA)

\begin{tabular}{lcccccccc}
\hline Parameters & $\begin{array}{c}\text { Sum of squares } \\
\text { between groups }\end{array}$ & $d f$ & $\begin{array}{c}\text { Mean square } \\
\text { between groups }\end{array}$ & $\begin{array}{c}\text { Sum of squares } \\
\text { within groups }\end{array}$ & $d f$ & $\begin{array}{c}\text { Mean square } \\
\text { within groups }\end{array}$ & $F$ & Observed $\alpha$ \\
\hline $\mathrm{Pb}$ & 12973.66 & 3 & 4324.55 & 20175.23 & 49 & 411.74 & 10.50 & $0.013^{*}$ \\
$\mathrm{Zn}$ & 895.5 & 3 & 298.5 & 1865.47 & 49 & 38.07 & 7.84 & 0.54 \\
$\mathrm{Cu}$ & 349.31 & 3 & 116.43 & 624.12 & 49 & 12.74 & 9.13 & $0.021^{*}$ \\
$\mathrm{Ni}$ & 248.14 & 3 & 82.71 & 347.45 & 49 & 7.09 & 11.66 & $0.044^{*}$ \\
$\mathrm{Cr}$ & 114.8 & 3 & 38.26 & 258.63 & 49 & 5.28 & 7.24 & 0.46 \\
\hline
\end{tabular}

$\alpha$, significant level

*Significant difference between the samples $(P$-value $<0.05)$

constituent of many enzymes of oxidation-reduction reactions (Raven and Johnson, 1986; Celik et al., 2005). Kabata-Pendias and Piotrowska (1984) reported the normal content of $\mathrm{Cu}$ in plants ranges to be 2-20 ppm, but in most plants, the normal $\mathrm{Cu}$ contents are in a lower range of 4-12 ppm. Results indicated that the lowest mean value of copper $(2.5$ ppm) was found in samples collected from the control site, but the highest mean copper value (15.43 ppm) was found in sample collected from a highway that has heavy traffic. The highest mean value of nickel, was found in samples collected from the highway sites $(16.7 \mathrm{ppm})$, whereas the lowest mean value was determined in a control site ( 1.86 $\mathrm{ppm})$. This high concentration is attributed to emissions from motor-vehicle that use nickel gasoline and by abrasion and corrosion of nickel from vehicle parts (Al-Shayeb and Seaward, 2001).
The level of chromium in the study area was generally low (Table 1). Cr is a toxic, non-essential element for plants (Shanker et al., 2005). Effects of $\mathrm{Cr}$ on plants are symptoms of chlorosis on leaves and decrease of root growth (Yagdi et al., 2000). In the study area, chromium pollution caused by engine and body erosion of automobiles and extensive road marking by yellow lead chromate paint and some industrial activities (Al-Shayeb et al., 1995).

\section{CONCLUSION}

Results of this study show that the highest and the lowest metal concentrations were found in the heavy traffic sites and control site, respectively. The mean values of metal concentrations are lower at the control site compared to all other sites. The variation in heavy metal concentrations between the 
increasing industrial and traffic activities in the city indicates the need for pollution control in the city environment. The result showed that Pinus Eldarica Medw. needles can be used as a simple way to monitor polluted sites.

\section{ACKNOWLEDGMENTS}

The authors thank the Islamic Azad University, Science and Research Branch for providing financial support for this project. Appreciation is extended to Miss Sara Pourabbasi, who helped during the collection and analysis of samples.

\section{REFERENCES}

Abdel-Ghani, N. T.; Hefny, M.; El-Chaghaby, G. A. F., (2007). Removal of lead from aqueous solution using low cost abundantly available adsorbents. Int. J. Environ. Sci. Tech., 4 (1), 67-74 (8 pages).

Adeniyi, A. A., (1996). Determination of cadmium, copper, iron, lead, manganese, and zinc in water leaf (Talinum triangularia) in dump sites. Environ. Int., 22 (2), 259262 (4 pages).

Allen, S. E., (1989). Chemical analysis of ecological materials.

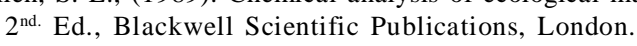

Allen, S. E.; Grimshow, H. M.; Parkinson, J. A.; Quarmby, C., (1974). Chemical analysis of ecological materials. Blackwell Scientific Publications, Osney Mead, Oxford, UK.

Al-Shayeb, S. M.; Al-Rajhi, M. A.; Seaward, M. R. D., (1995). The date palm (Phoenix dactylifera L.) as a biomonitor of lead and other elements in arid environments. Sci. Total Environ., 168 (1), 1-10 (10 pages).

Al-Shayeb, S. M.; Seaward, M. R. D., (2001). Heavy metal content of roadside soils along ring road in Riyadh (Saudi Arabia). Asian J. Chem., 13 (2), 407-423 (17 pages).

Babaoglu, M.; Gezgin, S.; Topal, A.; Sade, B.; Dural, H., (2004). Gypsophila sphaerocephala Fenzi ex Tchihat.: A boron hyperaccumulator plant species that may phytoremediate soils with toxic B levels. Tr. J. Botany., 28 (3), 273-278 (6 pages).

Boddy, L.; Frankland, J. C.; Dursun, S.; Newsham, K. K.; Ineson, P., (1994). Effects of sulphite and dry-deposited $\mathrm{SO}_{2}$ on fungi and decomposition of tree leaf litter. Fungi and Environmental Change, British Mycological Society $11^{\text {th. }}$ General Meeting, Cranfield University, Cranfield.

Bucher, A. S.; Schenk, M. K., (2000). Toxicity level for phytoavailable zinc in compost peat substrates. Sci. Hortic., 83 (3-4), 339-352 (14 pages).

Celik, A.; Kartal, A.; Akdogan, A.; Kaska, Y., (2005). Determination of heavy metal pollution in Denizli (Turkey) by using Robinio Pseudo-acacia L., Environ. Int., 31 (1), 105-112 (8 pages).

Duran, A. C.; Gonzalez, A., (2009). Determination of lead, naphthalene, phenanthrene, anthracene and pyrene in street dust. In. J. Environ. Sci. Tech., 6 (4), 663-670 (8 pages).

Dursun, S.; Ozdemir, C.; Guclu, D., (2002). Chemical treatment of the leather industry wastewater. J. Inst. Sci.
Tech., (Gazi University), 15 (2), 451-456 (6 pages).

Gbaruko, B. C.; Friday, O. U., (2007). Bioaccumulation of heavy metals in some fauna and flora. Int. J. Environ. Sci. Tech., 4 (2), 197-202 (6 pages).

Goodman, G. T .; Roberts, T. M., (1971). Plants and soils as indicators of metals in the air. Nature, 231 (5301), 287292 (6 pages).

Grodzinka, K., (1982). Monitoring of air pollutants by mosses and tree bark. In: Stuebing, L.; Jäger, H. J., (Eds). Monitoring of air pollutants by plants. The Hague, 33-42.

Gromov, S.; Emelina, E., (1994). Lead emission evaluation over the European part of the former Soviet Union. Sci. Total Environ., 158 (1-3), 135-137 (3 pages).

Huhn, G.; Schulz, H.; Stärk, H. J.; Töll, R.; Schüürmann, G., (1995). Evaluation of regional heavy metal deposition by multivariate analysis of element contents in pine tree barks. Water Air Soil Pollut., 84 (3-4), 367-383 (17 pages).

Kabata-Pendias, A.; Piotrowska, M., (1984). Zanieczyszczenie Glebi Roslin Uprawnych Pierwiastkami Sladowymi. CBR opracowanie problemowe, Warsazawa, Poland.

Kashem, M. A.; Singh, B. R.; Kondo, T.; Imamul huq, S. M.; Kawai, S., (2007). Comparison of extractability of Cd, $\mathrm{Cu}, \mathrm{Pb}$ and $\mathrm{Zn}$ with sequential extraction in contaminated and non-contaminated soils. Int. J. Environ. Sci. Tech., 4 (2), 169-176 (8 pages).

Kho, F. W. L.; Law, P. L.; Ibrahim, S. H.; Sentian, J., (2007). Carbon monoxide levels along roadway. Int. J. Environ. Sci. Tech., 4 (1), 27-34 (8 pages).

Koeppe, D. E., (1981). Lead: understanding the minimal toxicity of lead in plants. In: Lapp, N. W. (Ed.), Effects of trace metals on plant function. Applied Science Publishers, London, 55-76 (Chapter 2).

Li, X.; Poon, C.; Liu, P. S., (2001). Heavy metal contamination of urban soils and street dusts in Hong Kong. Appl. Geochem., 16 (11-12), 1361-1368 (8 pages).

Lippo, H.; Poikolainen, J.; Kubin, E., (1995). The use of moss, lichen and pine bark in the nationwide monitoring of atmospheric heavy metal deposition in Finland. Water, Air Soil Pollut., 85 (4), 2241-2246 (6 pages).

Löstschert, W.; Köhm, H. J., (1978). Characteristics of tree bark as an indicator in high emission areas: II. Content of heavy metals. Oecologia, 37 (1), 121-132 (12 pages).

Nabulo, G.; Oryem Origa, H.; Nasinyama, G. W.; Cole, D., (2008). Assessment of $\mathrm{Zn}, \mathrm{Cu}, \mathrm{Pb}$ and $\mathrm{Ni}$ contamination in wetland soils and plants in the lake basin. Int. J. Environ. Sci. Tech., 5 (1), 65-74 (10 pages).

Onasanya, L. O.; Ajewole, K.; Adeyeye, A., (1993). Lead content in roadside vegetation as indicator for atmospheric pollution. Environ. Int., 19 (6), 615-618 (4 pages).

Onder, S.; Dursun, S., (2006). Air borne heavy metal pollution of Cedrus libani (A. Rich.) in city center of Konya (Turkey). Atmospher. Environ., 40 (6), 1122-1133 (12 pages).

Onianwa, P. C.; Ajaya, S. O.; Osibanjo, O.; Egunyomi, A., (1986). Accumulation patterns of heavy metals in forest mosses from the south-west region of Nigeria. Environ. Pollut., (Series B)., 11 (1), 67-78 (12 pages).

Raven, P. H; Johnson, G. B., (1986). Biology. Times Mirror/ Mosby College Publishing, St. Louis. 
Salt, D. E.; Prince, R. C.; Pickering, I. J.; Raskin, I., (1995). Mechanisms of cadmium mobility and accumulation in Indian mustard. Plant Physio., 109 (4), 1427-1433 (7 pages).

Shanker, A. K.; Cervantes, C.; Loza-Tavera, H.; Avudainayagam, S., (2005). Chromium toxicity in plants. Enveiron. Int., 31 (5), 739-753 (15 pages).

Tehran Municipality, (2007). Internal report, data and files of the Green Space Organization. http://www.tehran.ir

Viard, B.; Pihan, F.; Promeyrat, S.; Pihan, J. C., (2004). Integrated assessment of heavy metal ( $\mathrm{Pb}, \mathrm{Zn}, \mathrm{Cd})$ highway pollution: bioaccumulation in soil, Graminaceae and land snails. Chemosphere, 55 (10), 1349-1359 (11 pages).

Wilkinson, R. E., (1994). Plant-environment interaction. Marcel Dekker, New York, 559.
Wolterbeek, H. T.; Kuik, P.; Verburg, T. G.; Wamelink, G. W.; Dobben, H. V., (1996). Relations between sulphate, ammonia, nitrate, acidity and trace element concentrations in tree bark in the Netherlands. Environ. Monit. Assess., 40 (2), 185-201 (17 pages).

Yagdi, K.; Kacar, O.; Azkan, N., (2000). Heavy metal contamination in soils and its effects in agriculture. J. Agri. (Faculty OMU). 15 (2), 109-115 (7 pages).

Yilmaz, S.; Zengin, M., (2004). Monitoring environmental pollution in Erzurum by chemical analysis of Scot pine (Pinus sylvestris L.) needles. Environ. Int., 29 (8), 10411047 (7 pages).

\section{AUTHOR (S) BIOSKETCHES}

Kord, B., Ph.D., Assistant Professor, Department of Green Space Engineering, Malayer Branch, Islamic Azad University, Malayer, Iran. P.O. Box 65718/117. Email: behrouzkord@yahoo.com

Mataji, A., Ph.D., Associate Professor, Department of Forestry, Science and Research Branch, Islamic Azad University, Tehran, Iran. Email: amataji@srbiau.ac.ir

Babaie, S., Ph.D., Assistant Professor, Department of Forestry, Science and Research Branch, Islamic Azad University, Tehran, Iran. Email: babaie47@yahoo.com

How to cite this article: (Harvard style)

Kord, B.; Mataji, A.; Babaie, S., (2010). Pine (Pinus Eldarica Medw.) needles as indicator for heavy metals pollution. Int. J. Environ. Sci. Tech., 7 (1), 79-84. 